\title{
Water Column Depth Dependence of Trace Metals, Inorganic Nutrients and Hydrocarbons in Caspian Seawater Taken from Areas of Azerbaijan
}

\author{
Majid Mirzaogli Ahmadov, Navai Ayubogli Ibadov and Valeh Salehogli Balayev \\ Institute of Radiation Problems of Azerbaijan NAS, 121 H.Javid aven, AZ1143, Baku, Azerbaijan
}

\begin{abstract}
The present study was conducted to investigate the heavy metal contents ( $\mathrm{As}, \mathrm{Ba}, \mathrm{Cu}, \mathrm{Ga}, \mathrm{Mo}, \mathrm{Rb}, \mathrm{U}$, and $\mathrm{V}$ ), inorganic nutrients $\left(\mathrm{NO}_{2}, \mathrm{NH}_{4}, \mathrm{NO}_{3}, \mathrm{PO}_{4}\right.$ and $\left.\mathrm{SiO}_{2}\right)$, THC and 16EPA PAHs in seawater samples, which were collected at two different sites of Azerbaijan sector of the Caspian Sea. The Agilent 7700x Series ICP-MS with HMI system is applied to analysis seawater. Inorganic nutrients defined by spectrocolorometry HACH DR5000. Dependence concentration of elements from water columns depth can be explained in accordance with the geochemical system of classification of dissolved forms of elements in the sea water. Hydrocarbons are extracted with methylene chloride, after the extracts are cleaned on silica-gel columns and then injected into GC/FID for determination of THC and GC/M Soperating in the selected-ion-monitoring mode for determination of the 16EPA PAHs. The average concentrations of THC were below the admissible environmental levels. THC ranged from $20-29 \mu \mathrm{g} / \mathrm{L}$ and PAHs from $<10-29 \mathrm{ng} / \mathrm{L}$, respectively.
\end{abstract}

Key words: ICP-MS, heavy metals, THC, 16EPA PAHS, GCFID, GC/MS SIM, Caspian Sea.

\section{Introduction}

The Caspian Sea is the largest lake on our planet. It is bigger than the Great American lakes and Lake Victoria in Africa by surface area. However, it is unique not only because of its size. As distinct from other lakes, the water of the Caspian is not fresh, but brackish. Each liter of Caspian water contains 10-13 g of salt making this water unsuitable for drinking or irrigation. However, the comparison of the Caspian water to oceanic water shows that it contains three times less salt than that of the World Ocean. Physically, the Caspian Sea is one of extremes. Its salinity varies greatly. Morphologically, the Sea is divided into three parts, the northern shallow part (average depth $6 \mathrm{~m}$ ), and the middle section with an average depth of $190 \mathrm{~m}$ (maximum depth $788 \mathrm{~m}$ ) and the southern Caspian with a maximum depth of 1,025 $\mathrm{m}$. The Caspian Sea occupies a deep depression on the

Corresponding author: Navai Ayubogli Ibadov,Ph. D., leading researcher, chemist, research field: environmental ecllogical. boundary between Asia and Europe with a water level at present $27 \mathrm{~m}$ below sea level. It is approximately $1,200 \mathrm{~km}$ long with a maximum breadth of $466 \mathrm{~km}$, contains $79,000 \mathrm{~km}^{3}$ of water, and has a total coastline of more than $7,000 \mathrm{~km}$. The Caspian is fed by five major rivers or river groups: in the north the Volga ( $80 \%$ of total inflow) and the Ural (5\%); in the west the Terek, Sulak and Samur (4-5\%) and the Kura (7-8\%); and in the south, the short mountain rivers from the Iranian Alborz range (4-5\%). Azerbaijan has more than $800 \mathrm{~km}$ of coastline along the Caspian Sea and almost the entire country is part of the Sea's catchment area. The littoral States of the Caspian Sea are the Republic of Azerbaijan, the Islamic Republic of Iran, the Republic of Kazakhstan, the Russian Federation and Turkmenistan [1-3]. Environmental problems of the Caspian Sea are multiple and various in their origin. On one hand, they are caused by the commercial use of the sea; on the other hand, human activity impacts coastal areas, including input from rivers in the Caspian. As the Caspian is an inland 
water body, anthropogenic (man-caused) impacts on catchment area (about 3.5 million $\mathrm{km}^{2}$ ) accumulate here. Anthropogenic impact on the Caspian ecosystem occurs concurrently with various natural endogenous and exogenous processes. It is primarily sea level changes, periodical seismic activity, surges and retreats, mud volcanoes and neo-tectonics. Special features of the Caspian include constant alterations of its area, volume, and configuration of the coastline and water column structure. Anthropogenic activity, as well as a natural impact, can have a chronic (long term) or acute (short term) effect. The sources of pollution are industrial, agricultural and accidental discharges and sewage. The main sources of pollution to the Caspian Sea have generally been considered to be offshore oil production and land-based sources, notably the Volga River. The presence of oil in the Caspian Sea region has been known since ancient times and the oil reserves were amongst the first to be exploited in the world. Baku was a centre for oil production at the turn of the 20th century and developed further development during the era of the Soviet Union. Exploration and exploitation, especially of offshore reserves, has blossomed since the breakup of the Soviet Union. Public opinion polls in the region have highlighted concerns about the oil and gas industry as a source of pollution to the environment of the Caspian Sea. Oil production areas cover vast areas of the coastal zone, particularly along the south coast of the Apsheron Peninsula in Azerbaijan. Population growth and industrial development in the Caspian region have generated an immense pollution problem. Ten million people live adjacent to the Caspian Sea and 60 million more live in the Volga River watershed. The World Bank estimates that one million cubic meters of untreated industrial wastewater is discharged into the Caspian annually. Soviet oil extraction left behind polluted soil and water, rusty equipment, and well fires that burned for years. Meanwhile, the five countries surrounding the sea are rushing to exploit still untapped oil deposits.
Since the Caspian is an enclosed body of water, it has limited carrying capacity compared to larger and more open bodies of water. Pollution entering the Caspian is either bio geochemically altered, or remains in the Sea for years; none escapes and dilution is limited from external buffering waters. In the former Soviet Union, water and sediment quality measurements were taken on a regular basis and with good coverage. In Azerbaijan, the situation reported to be changing, and the number of monitoring surveys has increased. Within the current situation, over the same period the flux of pollutants into the Caspian has changed, with a drastic reduction in industrial and agricultural activity in Turkmenistan, Kazakhstan, the Russian Federation and Azerbaijan [4-5].

The present study was conducted to investigate the heavy metal contents (As, $\mathrm{Ba}, \mathrm{Cu}, \mathrm{Ga}, \mathrm{Mo}, \mathrm{Rb}, \mathrm{U}$ and $\mathrm{V})$, Inorganic nutrients, THC (total hydrocarbons) and 16EPA Polynuclear aromatic hydrocarbons (16EPA PAHs) of seawater the Caspian sea were collected from 2 different sites with the geographic coordinates: ST\#1- Easting 506,110 and Northing 4,456,694; ST\#2Easting 538,557 and Northing 4,431,454 at different depth of water column, in Azerbaijan region. It is known that the analysis of ultra-trace elements in sea water samples is one of the most difficult analytical tasks in the field of environmental monitoring, as extremely low detection limits for elements buried in a highly saline matrix is required. The use of ICP-MS (inductively coupled plasma mass spectrometry) for direct sea water analysis is currently limited by spectral and non-spectral interferences caused by the sea water matrix.

To avoid this problem the Agilent 7700x Series ICP-MS applied to analysis sea water. The Agilent 7700x ICP-MS combines the simplicity of a single collision cell mode (helium mode) for polyatomic interference removal with the superior matrix tolerance of its unique High Matrix Introduction (HMI) system. In order to reduce salt deposition in the nebulizer the humidifier is used. The humidifier 
humidifies the carrier gas and reduces salt deposition in the nebulizer. Third generation ORS3 (Octopole Reaction System) cell technology provides higher sensitivity and more effective interference removal than ever before in complex, high matrix samples, eliminating the need for reactive cell gases in routine analysis. Helium mode on the ORS3 is so effective that interference correction equations can also be eliminated. These two factors redefine ease of use in ICP-MS, removing two of the most common causes of errors in multi-element analysis of complex samples.

Contact with oil in the environment as a result of the accident tanker accidents on oil platforms, drilling rigs, wells, as well as the release of any substance derived from crude oil, polluting the ecosystem of the sea water. Dealing with the consequences of such accidents takes from several months to several years, depending on the degree of contamination. For example, recent incidents at sea have led to large amounts of crude oil being released and dispersed throughout the Gulf of Mexico.

One of the most frequently tested for groups of compounds within petroleum and petroleum distillates are PAHs (polynuclear aromatic hydrocarbons). PAHs are comprised of aromatic rings which are strongly lipophilic. Larger PAH compounds are less water soluble and less volatile than smaller compounds and, therefore, pose more of a risk in nature. PAHs have been found to be carcinogenic, mutagenic, and petrogenic and can bioaccumulate within the environment. This being said, it is estimated that up to $30 \%$ (by weight) of crude oil are PAH compounds [6-9]. In environmental studies, the extent of PAH contamination as a group is often quantified by the concentrations of 16 of the representative PAH species, which are included in the list of priority pollutants as defined by USEPA [10-13]. GC/MS (gas chromatography with mass spectrometry) is presently the preferred analytical technique for the analysis of PAHs. As is often the case in environmental analysis, effective sample preparation and cleanup holds the key of success for the analysis of trace PAHs.

\section{Materials and Methods}

Water samples, collected from surface and bottom seawater layer with a 12-liter PVC Niskin sampler equipped with a Teflon-coated spring, suspended from stainless steel hydro wire and allowed to flush for 5 min before closing, in acid cleaned polythene containers for metals and in amber glass bottles for the hydrocarbons, packed and transported in ice-box for analysis. Surface samples were collected from all sites a depth not exceeding 5 meter (surface), whereas bottom samples were collected from sites at depths 50 , 100, 200 and 350 meters.

For the metals, all plastic-ware sample bottles, pipette tips, filtration unit and flasks were soaked in $10 \% \mathrm{v} / \mathrm{v} \mathrm{HNO}_{3}$ for $24 \mathrm{~h}$ and rinsed with ultra-pure water before being used. Milli-Q ultra-pure water (resistivity 18.2 $\mathrm{M} \Omega \mathrm{cm}, \mathrm{pH}$ (5.5-6.5)) was used throughout, and all laboratory operations. In the laboratory by adding an appropriate volume of nitric acid the acid concentration of the samples are adjusted to approximate at $1 \%(\mathrm{v} / \mathrm{v})$ nitric acid solution. An Agilent 7700x ICP-MS system was used to measure each sample in helium mode, using standard Agilent-recommended auto tuning for robust tuning conditions (around $1.0 \% \mathrm{CeO} / \mathrm{Ce}$ ). Agilent's new HMI (high matrix introduction) accessory for the 7700x and 7700s ICP-MS systems permits the direct analysis of samples containing percent level dissolved solids including neat seawater without prior dilution. The HMI accessory uses a combination of highly optimized robust plasma conditions and a technique termed "aerosol dilution". The net effect is a reduction in the amount of sample and solvent reaching the plasma and MS interface of up to $30 \mathrm{x}$ compared to a standard system. This reduction leads to higher plasma temperature, reduced suppression, improved stability and significantly lowers oxides.

The samples were analyzed for $\mathrm{As}, \mathrm{Ba}, \mathrm{Cu}, \mathrm{Ga}, \mathrm{Mo}$, $\mathrm{Rb}, \mathrm{U}$ and $\mathrm{V}$ using an Agilent model 7700x ICP-MS. 
Multi-element calibration working standards solutions were prepared by appropriate dilution of from $10 \mathrm{mg} / \mathrm{L}$ multi-element stock standard solutions-(Part\#8500-6940 in $\left.5 \% \mathrm{HNO}_{3}\right)$ in $1 \%$ $\mathrm{HNO}_{3}$ correspondingly. The blank and calibration solutions were measured under optimized conditions. The calibration curve was automatically plotted by the instrument. Linear correlation coefficient (r) in all calibration curves were better than 0.9995 . Instrument drift and matrix effects during measurement were corrected by using the internal standards include $\mathrm{Sc}, \mathrm{Ge}, \mathrm{Rh}, \mathrm{In}, \mathrm{Tb}$ and $\mathrm{Bi}$ were prepared by appropriate dilution from stock ICP-MS Internal Standard Mix Part\# 5188-6525 and added on-line at the time of analysis using a second channel of the peristaltic pump. For quality control purposes, duplicate samples, matrix-spike sample were analyzed.

$\mathrm{SiO}_{2}$ determination method is based on the reaction of the soluble silica with molybdate ion to form a greenish yellow complex, which in turn is converted to a blue complex by reduction with 1-amino-2-naphthol-1-sulfonic acid [30]. Silica calibration working standards solutions were prepared by appropriate dilution from Silica Solution, Standard ( $1 \mathrm{~mL}=0.1 \mathrm{mg} \mathrm{SiO})_{2}$.

In the determination of $\mathrm{PO}_{4}$ used reaction of ammonium molybdate and antimony potassium tartrate in an acid medium with dilute solutions of phosphorus to form an antimony-phospho-molybdate complex. This complex is reduced to an intensely blue-colored complex by ascorbic acid. The color is proportional to the phosphorus concentration [31]. For the preparation of standard solution transferred, by means of a volumetric pipette, appropriate volumes: $1 \mathrm{~mL} ; 2 \mathrm{~mL}$; $3 \mathrm{~mL} ; 4 \mathrm{~mL} ; 5 \mathrm{~mL} ; 6 \mathrm{~mL} ; 7 \mathrm{~mL} ; 8 \mathrm{~mL} ; 9 \mathrm{~mL}$ and 10 $\mathrm{mL}$ of the orthophosphate standard solution to $50 \mathrm{~mL}$ volumetric flask and diluted with water to about $40 \mathrm{~mL}$. These solutions represent orthophosphate concentration $0.05 \mathrm{mg} / \mathrm{L}$ to $0.5 \mathrm{mg} / \mathrm{LP}$.

For the measurement of $\mathrm{NO}_{3}$ it is reduced almost quantitatively to nitrite $\left(\mathrm{NO}_{2}\right)$ - in the presence of cadmium $(\mathrm{Cd})$. The $\mathrm{NO}_{2}$ produced thus is determined by diazotizing with sulfanilamide and coupling with $\mathrm{N}$-(1-naphthyl)-ethylene diaminedihydrochloride to form a highly colored azo dye that is measured calorimetrically [32].

Using the intermediate $\mathrm{NO}_{3}-\mathrm{N}$ solution, prepared standards in the range 0.05 to $1.0 \mathrm{mg} / \mathrm{L} \mathrm{NO}_{3}-\mathrm{N}$ by diluting the following volumes to $100 \mathrm{~mL}$ in volumetric flasks: $0.5,1.0,2.0,5.0$, and $10.0 \mathrm{~mL}$.

For the hydrocarbons, samples preserved at the time of sampling by the addition of a suitable acid to reduce the $\mathrm{pH}$ of the sample to less than 2.0. This is accomplished by the addition of $5 \mathrm{~mL}$ of $1: 1 \mathrm{HCl}$ to a $1 \mathrm{~L}$ sample. Following collection and addition of acid, the sample must be cooled to $4 \pm 2{ }^{\circ} \mathrm{C}$. Samples are extracted with methylene chloride by EPAMethod-3510C (Separatory funnel Liquid-Liquid Extraction) and cleaned by EPAMethod-3660B (Sulfur clean-up) and EPA-Method-3630C (Silica-Gel Cleanup) [14-19]. Concentrate extracts by Kuderna-Danish apparatus at $50-55{ }^{\circ} \mathrm{C}$ till $2 \mathrm{~mL}$ and transfer extract into volumetric tube. After placing the volumetric tube in nitrogen blow-down apparatus, evaporate the extract till $1 \mathrm{~mL}$ and the THC (total hydrocarbons) are analyzed on a gas chromatograph with a flame ionization detector (GC7890B, Agilent) and PAHs analyzed by GC/MS (Thermo-Electron, Finnigan) SIM modes.

\subsection{GC/FID Analysis}

The hydrocarbons are analyzed on a gas chromatograph with a flame ionization detector (GC-FID) by GC7890B (Agilent), and the THCs are usually estimated by integrating the areas of peaks [20]. For GC/FID calibration mix used C7-C40 Saturated Alkanes (Sigma Aldrich, Cat\#49452-U). Hexadecane-d34 and squalane are used as internal standards for calculations and 5-alpha-Androstane as surrogate for the THC. The internal standard solutions are added to all samples and quality control samples 
just prior to extraction procedures. Chromatographic separation of THC was accomplished on a CP-Sil 5CB (100\% dimethylpolysiloxane) capillary column $(15 \mathrm{~m} \times 0.25 \mathrm{~mm}$ I.D., $0.25 \mathrm{~mm}$ film thickness). Nitrogen was the carrier gas and a pressure $15 \mathrm{psi}$ (constant) was used for column elution. Sample injection was carried out in the splite/splitless mode with an injection volume of $1 \mu \mathrm{L}$. The $\mathrm{GC}$ oven temperature was programmed first from $40{ }^{\circ} \mathrm{C}$ (hold 2 $\min$ ), $40{ }^{\circ} \mathrm{C}$ to $320^{\circ} \mathrm{C}$ at a rate of $10{ }^{\circ} \mathrm{C} / \mathrm{min}$ (hold 2.0 min). FID temperature was $325{ }^{\circ} \mathrm{C}$ (Make-up-30 $\mathrm{mL} / \mathrm{min}$ Hydrogen- $30 \mathrm{~mL} / \mathrm{min}$, Air- $300 \mathrm{~mL} / \mathrm{min}$ ). The temperatures of the injection port were set at $300{ }^{\circ} \mathrm{C}$. Software acquisition is Chemstation, capable of continuous acquisition and storage of all data during analysis [22].

\subsection{GC/MS-SIM Analysis}

A GC/MS (gas chromatograph/mass spectrometer) in SIM (selected ion mode) coupled to a capillary column is used to resolve, detect and quantitate PAH (polycyclic aromatic hydrocarbons) in solids at parts per billion levels. Samples are injected into a temperature-programmed GC/MS, operated in splitless mode. The capillary column is a DB-5MS (30 $\mathrm{m} \times 0.25 \mathrm{~mm}$ ID and $0.25 \mathrm{~mm}$ film thickness). The mass spectrometer is capable of scanning from 50 to 500 AMU every second or less and uses 70 electron volts energy in electron impact ionization mode. Software-Thermo Electron-Finnigan Technologies Xcalibur 1.4SR1, is capable of continuous acquisition and storage of all data during analysis. For identifications of components used 4 segments (in the each segments present 12 ions), for each segments scan time equal to $1.39 \mathrm{~s}$ and dwell time $0.1 \mathrm{sec}$ per ion [21].

The standard solution is made from aliquots of mixture (Z-014J-PAK; M-525-SS-PAK; M-8310-SS-PAK, Accu Standard, Inc., USA) or pure compounds and diluted with dichloromethane to a final concentration of $0.25 \mathrm{ug} / \mathrm{mL}$. The standards solution includes naphtalene-d8, acenaphthene-d10, phenantrene-d10, pyrene-d10, chrysene-d12 and perylene-d12. The internal standard compounds are resolved from, but elute in close proximity to the analytes of interest.

The internal standard solution is added to all samples and quality control samples just prior to extraction procedures. Internal standards are used to calculate relative response factors and specific analyte concentrations based on retention time [22].

\section{Results and Discussion}

The results analyze heavy metals and hydrocarbons in sea water samples taken in two sites at a different depth of surface $5 \mathrm{~m}, 50 \mathrm{~m}, 100 \mathrm{~m}, 200 \mathrm{~m}$ and $350 \mathrm{~m}$. Dependence concentrations of analyses elements from depth of water column are demonstrated that for both sites there were nearly identical variation concentrations of $\mathrm{As}, \mathrm{Ba}, \mathrm{Ga}$ and $\mathrm{V}$ from depth of water column. Gradual decrease concentration with increasing water column depth was observed for elements $\mathrm{Cu}$ in station 1 and in station 2 respectively. Practically it is not significantly deference of the Mo, $\mathrm{Rb}$ and $\mathrm{U}$ concentrations in different column water depths in both sites. In accordance with the geochemical system of classification of dissolved forms of elements in the sea water [23, 24], the microelements in Table 1 are subdivided into conservative (Mo, $\mathrm{Rb}$ and $\mathrm{U}$ ), biogenic ( $\mathrm{V}, \mathrm{Ga}$, As and $\mathrm{Ba})$ and lithogenic $(\mathrm{Cu})$. Conservative-type trace metals interact only weakly with particles, and have concentrations that maintain relatively constant (in space and time) ratio to salinity. Trace metals with conservative-type distributions in seawater such as Molybdenum, Rubidium and Uranium are involved in the major biogeochemical cycles of particle formation and destruction, but this is negligible relative to their concentration in seawater. Trace metals with biogenic-type distributions are significantly involved with the internal cycles of biologically derived particulate material. Their distributions are dominated 
by the internal cycle of assimilation by plankton in surface waters and the export production or transport of part of this material out of the surface layer followed by oxidation and remineralization of the bulk of this material in deeper waters. Consequently, their concentrations are lowest in surface waters where they are assimilated by phytoplankton and/or adsorbed by biogenic particles, and increase in the subsurface waters as sinking particles undergo decomposition or dissolution. Trace metals with lithogenic-type distributions have strong interactions with particles. Their concentrations tend to be maximal near major sources such as rivers, atmospheric dust, bottom sediments, and hydrothermal vents. Concentrations decrease with distance from the sources and, in general, the concentrations of the scavenged metals tend to decrease along the flow path of deep water due to continual particle scavenging $[25,26]$.

Table 1 Concentration of metals in different depth of water column.

\begin{tabular}{llllllllll}
\hline \multirow{2}{*}{ Station } & Depth & $\mathrm{V}$ & $\mathrm{Cu}$ & $\mathrm{Ga}$ & $\mathrm{As}$ & $\mathrm{Rb}$ & $\mathrm{Mo}$ & $\mathrm{Ba}$ & $\mathrm{U}$ \\
\cline { 2 - 10 } & metr & $\mathrm{ug} / \mathrm{L}$ & $\mathrm{ug} / \mathrm{L}$ & $\mathrm{ug} / \mathrm{L}$ & $\mathrm{ug} / \mathrm{L}$ & $\mathrm{ug} / \mathrm{L}$ & $\mathrm{ug} / \mathrm{L}$ & $\mathrm{ug} / \mathrm{L}$ & $\mathrm{ug} / \mathrm{L}$ \\
\hline \multirow{6}{*}{ ST\#1 } & Surface & 0.788 & 0.852 & 0.996 & 1.475 & 8.166 & 16.873 & 12.095 & 6.324 \\
& 50 & 0.871 & 0.758 & 2.356 & 1.760 & 8.371 & 16.879 & 15.557 & 6.281 \\
& 100 & 0.944 & 0.723 & 2.789 & 2.726 & 8.852 & 16.939 & 26.686 & 6.278 \\
& 200 & 0.976 & 0.634 & 3.087 & 3.186 & 8.261 & 16.941 & 32.979 & 6.467 \\
& 350 & 1.026 & 0.626 & 3.603 & 3.414 & 8.759 & 17.075 & 44.166 & 6.362 \\
\hline \multirow{3}{*}{ ST\#2 } & Surface & 0.780 & 0.870 & 1.210 & 1.474 & 8.574 & 16.754 & 13.211 & 6.522 \\
& 50 & 0.807 & 0.799 & 1.708 & 1.659 & 8.695 & 16.771 & 16.382 & 6.657 \\
& 100 & 0.990 & 0.785 & 2.752 & 2.589 & 8.146 & 16.986 & 27.765 & 6.659 \\
& 200 & 1.031 & 0.672 & 3.468 & 3.211 & 8.285 & 17.185 & 34.639 & 6.618 \\
\hline
\end{tabular}

Table 2 Average concentration metals in sea water.

\begin{tabular}{llllllllll}
\hline & Depth & $\mathrm{V}$ & $\mathrm{Cu}$ & $\mathrm{Ga}$ & $\mathrm{As}$ & $\mathrm{Rb}$ & $\mathrm{Mo}$ & $\mathrm{Ba}$ & $\mathrm{U}$ \\
\cline { 2 - 10 } & metr & $\mathrm{ug} / \mathrm{L}$ & $\mathrm{ug} / \mathrm{L}$ & $\mathrm{ug} / \mathrm{L}$ & $\mathrm{ug} / \mathrm{L}$ & $\mathrm{ug} / \mathrm{L}$ & $\mathrm{ug} / \mathrm{L}$ & $\mathrm{ug} / \mathrm{L}$ & $\mathrm{ug} / \mathrm{L}$ \\
\hline & Surface & 0.784 & 0.861 & 1.103 & 1.475 & 8.370 & 16.813 & 12.653 & 6.423 \\
Average of both stations & 50 & 0.839 & 0.779 & 2.032 & 1.710 & 8.533 & 16.825 & 15.970 & 6.469 \\
& 100 & 0.967 & 0.754 & 2.770 & 2.658 & 8.499 & 16.962 & 27.225 & 6.469 \\
& 200 & 1.003 & 0.653 & 3.278 & 3.198 & 8.273 & 17.063 & 33.809 & 6.542 \\
& 350 & 1.031 & 0.619 & 3.701 & 3.404 & 8.564 & 16.792 & 43.662 & 6.377 \\
\hline
\end{tabular}

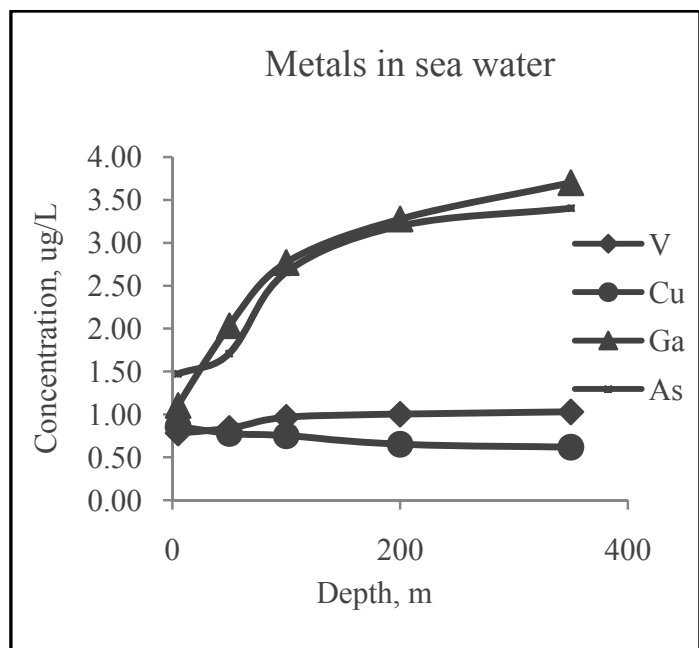

Metals in sea water

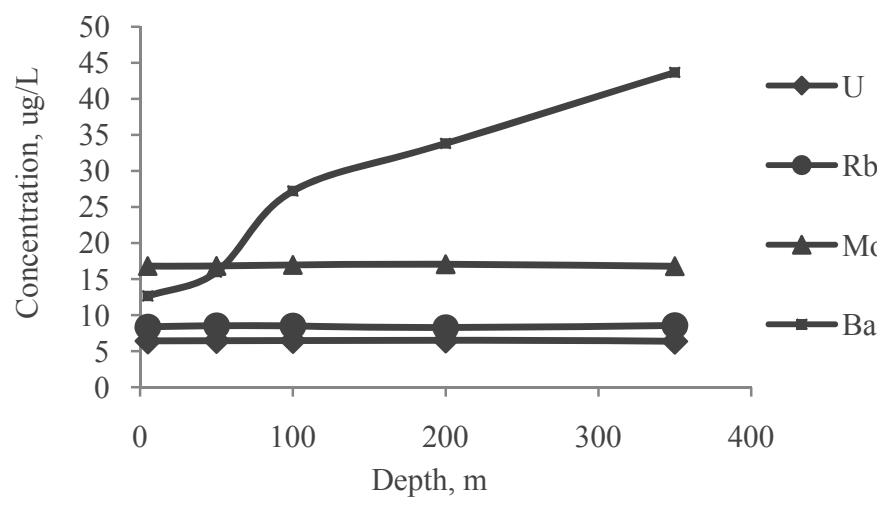

Fig. 1 Dependence average concentrations of metal from water column depths. 
The residual of 16 polynuclear aromatic hydrocarbons (naphthalene, acenaphthylene, acenaphthane, fluorene, phenathrene, anthracene, fluoranthene, benz (a) anthracene, chrysene, benzo (b) fluoranthene, benzo(k)fluoranthene, pyrene, benzo (a) pyrene, dibenzo(a,h)anthracene, benzo(ghi)perylene and indeno(1,2,3-cd)pyrene) and total petroleum hydrocarbons were investigated in Caspian sea water of Absheron areas.

Phenanthrene and fluorene were discovered on the surface and a depth of $50 \mathrm{~m}$ to $100 \mathrm{~m}$. The concentration of the other components PAHs, these values were significantly lower the method detection limit $(M D L=10 \mathrm{ng} / \mathrm{L})$. And to a deeper depth $(200 \mathrm{~m}$ and $350 \mathrm{~m}$ ), all the components comply with values below the MDL (Table 3 ).
Due to the lower density of oil products, which remain on the water surface, on the surface, $50 \mathrm{~m}$ and $100 \mathrm{~m}$ hydrocarbons were relatively higher than at the depth sea water bottom. And the THC becomes about 20 $\mathrm{ug} / \mathrm{L}$ at deeper locations (Method detection limit for $\mathrm{THC}=20 \mathrm{ug} / \mathrm{L})$ (Tables 3 and 4 and Figs. 2 and 3).

These concentrations are much lower than that given by Refs. [27-29].

The THC concentration in seawater which can produce a harmful effect on the aquatic organisms is in the range of $50 \mu \mathrm{g} / \mathrm{L}$ in sea water. In our studies, the maximum value of THC concentrations is equal to $29 \mu \mathrm{g} / \mathrm{L}$, which is less than the value indicated by Refs. [27-29].

In Table 5 and Fig. 4, present results of inorganic nutrients.

Table 3 Concentration of PAHs in different depth of sea water column.

\begin{tabular}{llllllllllll}
\hline Station & Unit & & \multicolumn{3}{c}{ ST\#1 } & & & \multicolumn{2}{c}{ ST\#2 } \\
\hline Depth & $\mathrm{metr}$ & Surface & 50 & 100 & 200 & 350 & Surface & 50 & 100 & 200 & 350 \\
\hline Naphthalene & $\mathrm{ng} / \mathrm{L}$ & $<10$ & $<10$ & $<10$ & $<10$ & $<10$ & $<10$ & $<10$ & $<10$ & $<10$ & $<10$ \\
Acenaphthylene & $\mathrm{ng} / \mathrm{L}$ & $<10$ & $<10$ & $<10$ & $<10$ & $<10$ & $<10$ & $<10$ & $<10$ & $<10$ & $<10$ \\
Acenaphthene & $\mathrm{ng} / \mathrm{L}$ & $<10$ & $<10$ & $<10$ & $<10$ & $<10$ & $<10$ & $<10$ & $<10$ & $<10$ & $<10$ \\
Fluorene & $\mathrm{ng} / \mathrm{L}$ & 12 & 10 & $<10$ & $<10$ & $<10$ & 13 & 11 & $<10$ & $<10$ & $<10$ \\
Phenanthrene & $\mathrm{ng} / \mathrm{L}$ & 21 & 14 & 13 & $<10$ & $<10$ & 11 & 10 & 12 & $<10$ & $<10$ \\
Anthracene & $\mathrm{ng} / \mathrm{L}$ & $<10$ & $<10$ & $<10$ & $<10$ & $<10$ & $<10$ & $<10$ & $<10$ & $<10$ & $<10$ \\
Fluoranthene & $\mathrm{ng} / \mathrm{L}$ & $<10$ & $<10$ & $<10$ & $<10$ & $<10$ & $<10$ & $<10$ & $<10$ & $<10$ & $<10$ \\
Pyrene & $\mathrm{ng} / \mathrm{L}$ & $<10$ & $<10$ & $<10$ & $<10$ & $<10$ & $<10$ & $<10$ & $<10$ & $<10$ & $<10$ \\
Benzo(a)anthracene & $\mathrm{ng} / \mathrm{L}$ & $<10$ & $<10$ & $<10$ & $<10$ & $<10$ & $<10$ & $<10$ & $<10$ & $<10$ & $<10$ \\
Chrysene & $\mathrm{ng} / \mathrm{L}$ & $<10$ & $<10$ & $<10$ & $<10$ & $<10$ & $<10$ & $<10$ & $<10$ & $<10$ & $<10$ \\
Benzo(b)fluoranthene & $\mathrm{ng} / \mathrm{L}$ & $<10$ & $<10$ & $<10$ & $<10$ & $<10$ & $<10$ & $<10$ & $<10$ & $<10$ & $<10$ \\
Benzo(k)fluoranthene & $\mathrm{ng} / \mathrm{L}$ & $<10$ & $<10$ & $<10$ & $<10$ & $<10$ & $<10$ & $<10$ & $<10$ & $<10$ & $<10$ \\
Benzo(a)pyrene & $\mathrm{ng} / \mathrm{L}$ & $<10$ & $<10$ & $<10$ & $<10$ & $<10$ & $<10$ & $<10$ & $<10$ & $<10$ & $<10$ \\
Indeno(123cd)pyrene & $\mathrm{ng} / \mathrm{L}$ & $<10$ & $<10$ & $<10$ & $<10$ & $<10$ & $<10$ & $<10$ & $<10$ & $<10$ & $<10$ \\
Benzo(ghi)perylene & $\mathrm{ng} / \mathrm{L}$ & $<10$ & $<10$ & $<10$ & $<10$ & $<10$ & $<10$ & $<10$ & $<10$ & $<10$ & $<10$ \\
Dibenzo(ah)anthracene & $\mathrm{ng} / \mathrm{L}$ & $<10$ & $<10$ & $<10$ & $<10$ & $<10$ & $<10$ & $<10$ & $<10$ & $<10$ & $<10$ \\
Total 16EPA PAHs & $\mathrm{ng} / \mathrm{L}$ & 34 & 24 & 13 & $<10$ & $<10$ & 24 & 21 & 12 & $<10$ & $<10$ \\
\hline
\end{tabular}

Table 4 Average concentration THC and 16EPA PAHs in different depth of sea water column.

\begin{tabular}{|c|c|c|c|c|c|c|}
\hline \multirow{3}{*}{ Deeps, $m$} & \multicolumn{2}{|c|}{ ST\#1 } & \multicolumn{2}{|c|}{ ST\#2 } & \multicolumn{2}{|c|}{ Average of both stations } \\
\hline & THC & Total EPA 16 & THC & Total EPA 16 & THC & Total 16EPA PAHs \\
\hline & $\mathrm{ug} / \mathrm{L}$ & $\mathrm{ng} / \mathrm{L}$ & $\mathrm{ug} / \mathrm{L}$ & $\mathrm{ng} / \mathrm{L}$ & $\mathrm{ug} / \mathrm{L}$ & $\mathrm{ng} / \mathrm{L}$ \\
\hline Surface & 29 & 34 & 25 & 24 & 27 & 29 \\
\hline 50 & 28 & 24 & 23 & 21 & 26 & 23 \\
\hline 100 & 27 & 13 & 21 & 12 & 24 & 13 \\
\hline 200 & 22 & $<10$ & 20 & $<10$ & 21 & $<10$ \\
\hline 350 & 20 & $<10$ & 20 & $<10$ & 20 & $<10$ \\
\hline
\end{tabular}



Caspian Seawater taken from Areas of Azerbaijan

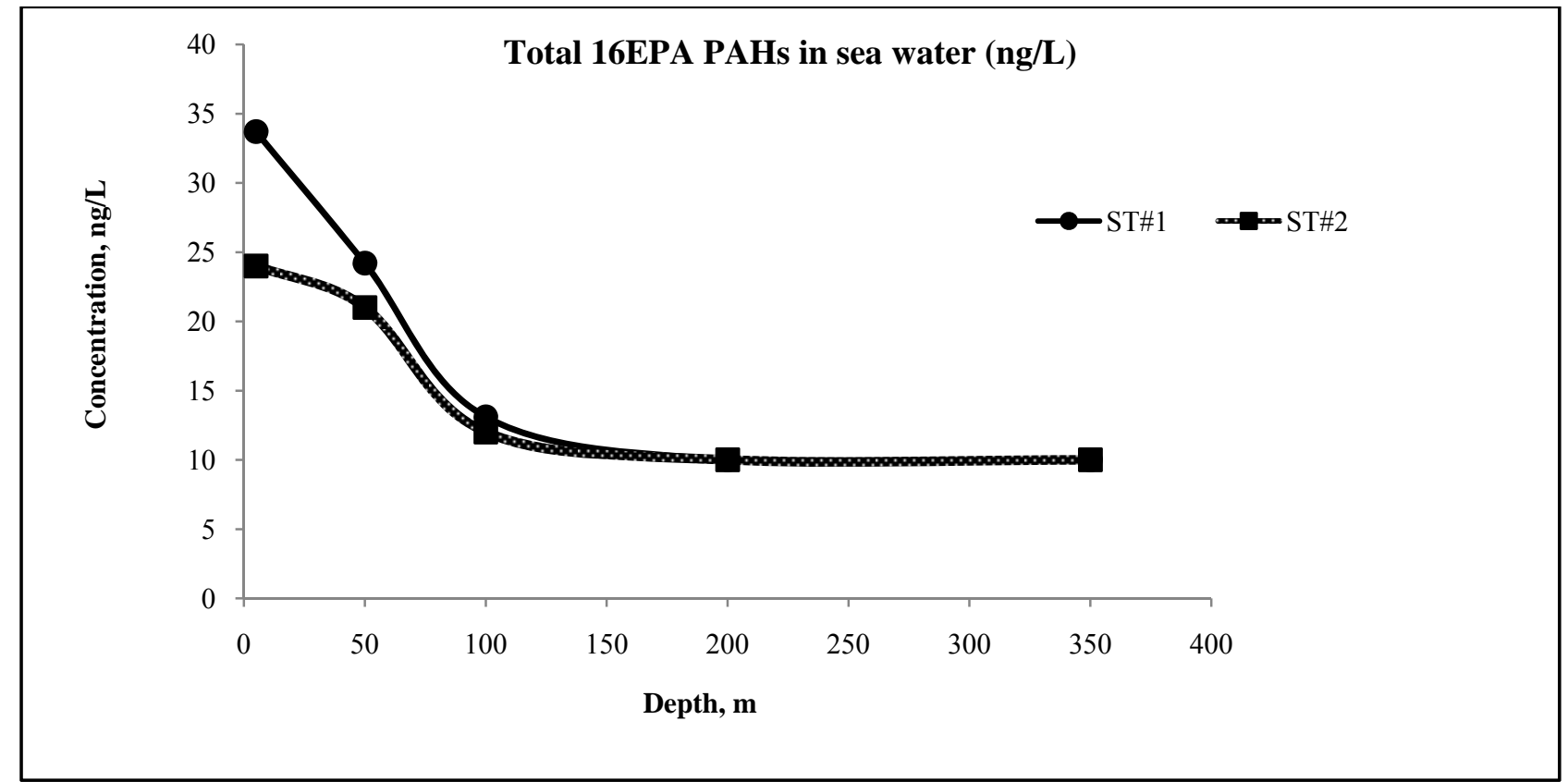

Fig. 2 Concentration of total 16EPA PAHs in different depth of sea water column.

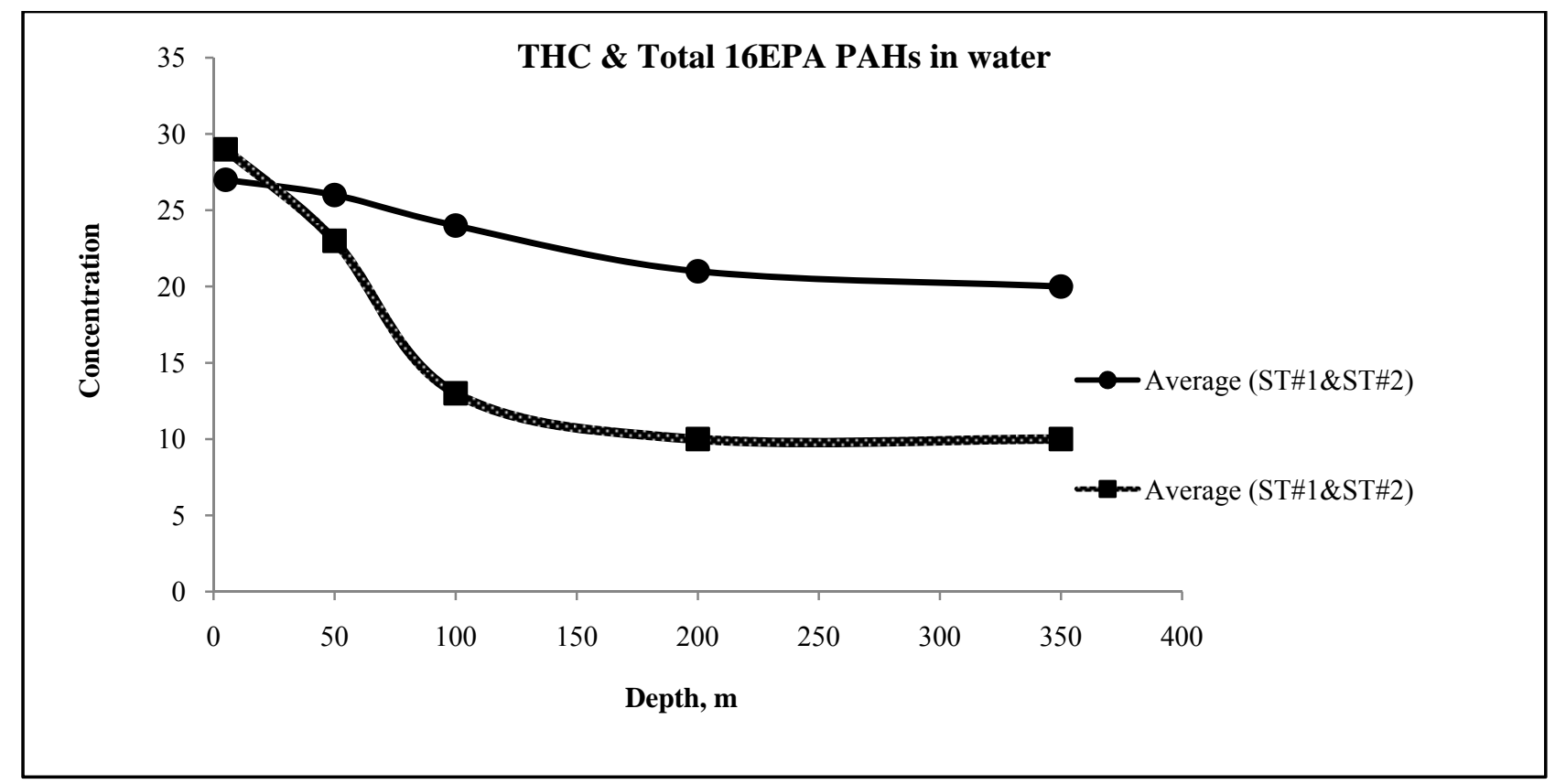

Fig. 3 Average concentration THC and 16EPA PAHs in different depth of sea water column.

Table 5 Concentration of nutrients in different depth of sea water column.

\begin{tabular}{lllllllllll}
\hline Station & \multicolumn{9}{c}{ ST\#1 } & \multicolumn{5}{c}{ ST\#2 } \\
\hline Depth, metr & Surface & 50 & 100 & 200 & 350 & Surface & 50 & 100 & 200 & 350 \\
\hline $\mathrm{NO}_{2}+3-\mathrm{N}$ & $<10$ & $<10$ & 33 & 118 & 156 & $<10$ & 19 & 38 & 80 & 131 \\
$\mathrm{PO}_{4}-\mathrm{P}$ & $<1$ & $<1$ & 2.1 & 16.7 & 29 & $<1$ & 1 & 3.6 & 9.8 & 25 \\
$\mathrm{SiO}_{2}-\mathrm{Si}$ & 11.6 & 83 & 448 & 754 & 1,443 & 82 & 318 & 520 & 745 & 1,379 \\
\hline
\end{tabular}



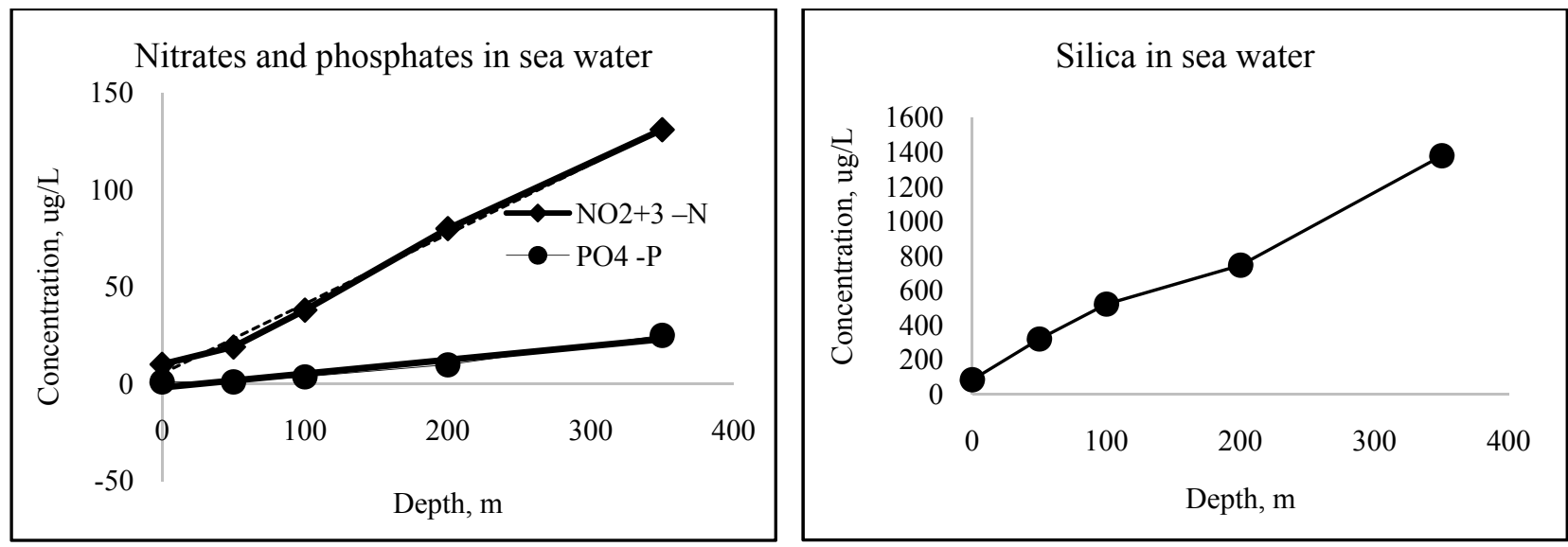

Fig. 4 Concentration of Nitrates, Phosphates and Silica in different depth of sea water column.

\section{Conclusions}

The Agilent 7700x Series ICP-MS (inductively coupled plasma mass spectrometry) with HMI (high matrix introduction) system is applied to analyze seawater. Depending on concentration of elements from water column depths are different for investigated metals and can be explained in accordance with the geochemical system of classification of dissolved forms of elements in the sea water.

GC/FID (GC7890B, Agilent) and GC/MS (TRACE/DSQ, Thermo-Electron-Finnigan) operating in the SIM (selected-ion-monitoring) mode are used for determination of the hydrocarbons and 16EPA PAHs, respectively. The average concentrations of total hydrocarbons were below the admissible environmental levels. THC ranged from 20-29 $\mu \mathrm{g} / \mathrm{L}$ and PAHs from $<10-29 \mathrm{ng} / \mathrm{L}$, respectively.

Nutrients (nitrate, phosphate and silicate) are low in surface waters as these are consumed during the biological production. Below the surface mixed layer their concentrations in seawater increase since the organic material decomposition occurs and the released materials accumulate in subsurface waters over time.

\section{References}

[1] Kosarev, A. N., and Yablonskaya, E. A. 1994. The Caspian Sea. Hague: SPB Academic Publishing, 274.

[2] Klinge, R. K., and Myagkov, M. S. 1992. "Changes in the Water Regime of the Caspian Sea." Geojournal 23: 299-307.
[3] Kosarev, A. N., and Tuhylkin, V. C. 1995. "Climatic Thermohaline Fields of the Caspian Sea." In Annual Report of Hydrometeorological Service of Russia, Moscow.

[4] Dumont, H. 1995. "Ecocide in the Caspian Sea." Nature 377: 673-4.

[5] Blinov, L. K. 1962. "The Physico-Chemical Properties of Caspian Waters and Their Comparable Characteristics." Trudi Gos. Okeanograf. Inst. (GOIN) 68: 7-28.

[6] N. Furata and A. Otsuki, Anal. Chem, 55, 2407-2013 (1983);

[7] Nieva-Cano, M. J., Rubio-Barroso, S., and Santos Delgado, M. J. 2001. "Carcinogenic and Mutagenic Properties of PAHs." Analyst 126: 132-40.

[8] Neff, J. M. 1985. "Polycyclic Aromatic Hydrocarbons." In Fundamentals of Aquatic Toxicology, edited by Rand, G. M., and Petrocelli, S. R. New York: Hemisphere.

[9] IARC. 1991. Monographs on Evaluation of Polynuclear Aromatic Compounds, Part 1, Chemical, Environmental, and Experimental Data. Lyon: Internal Agency for Research on Cancer.

[10] Neff, J. M. 1979. Polycyclic Aromatic Hydrocarbons in the Aquatic Environment. London: Applied Science Publishers.

[11] Bjorseth, A. 1983. Handbook of Polycyclic Aromatic Hydrocarbons.

[12] Blumer, M.W. 1976. "Polycyclic Aromatic Compounds in Nature." Sci. Am. 234: 34-45.

[13] Blumer, M. and Youngblood, W. W. 1975. "Polycyclic Aromatic Hydrocarbons in Soils and Recent Sediments." Science 188 (4183): 53-5.

[14] SW-846 EPA Test Method 3510C: Separatory Funnel Liquid-Liquid Extraction.

[15] SW-846 EPA Test Method 3660B Sulfur Cleanup.

[16] SW-846 EPA Test METHOD 3630C Silica Gel Cleanup.

[17] MADEP (Massachusetts Department of Environmental Protection). METHOD for the 
Determination of EPH (Extractable Petroleum Hydrocarbons), May 2004, Rev.1.1.

[18] SW-846 EPA Test EPAMETHOD 8270C Semivolatile Organic Compounds by Gas Chromatography/Mass Spectrometry (GC/MS).

[19] Ukenvironment Agency-A guide to Practices, Procedures and Methodologies Following Oil Spill Contamination Incidents (2004, pp.108). Methods for the Examination of Waters and Associated Materials.

[20] Douglas, G. S., McCarthy, K. J., Dahlen, D. T., Seavey, J. A., Steinhauer, W. G., Prince, R. C., and Elmendorf, D. L. 1992. "The Use of Hydrocarbon Analyses for Environmental Assessment and Remediation.” Journal of Soil Contamination 3 (1): 197-216.

[21] Kimbrough, K. L., Lauenstein, G. G., and Johnson, W. E. (Editors). 2006. Organic Contaminant Analytical Methods of the National Status and Trends Program: Update 2000-2006. NOAA Technical Memorandum NOS NCCOS 30. 137 pp., June 2007. //Thomas J. McDonald, Bo Wang, Susanne J. McDonald and James M. Brooks. CHAPTER 5. Quantitative Determination Of Aromatic Hydrocarbons Using Selected Ion Monitoring Gas Chromatography/Mass Spectrometry TDI-Brooks International./B\&B Laboratories Inc. College Station, Texas 77845//.

[22] Navai, A. I., and Bahruz, A. S. 2015. "Determination of Total Hydrocarbons and Alkyl PAHs in Sediments from
Apsheron Peninsula in Caspian Sea." Biological and Chemical Research 3 (5): 111-22.

[23] Korzh, V. D. 1991. Geochemistry of the Hydrosphere Composition in Terms of Elements. Moskow: Nayka.

[24] Bruland, K. W. 1983. Trace Metals in Sea Water. Chemical Oceanography. Vol. 8. London: Academic Press.

[25] John, R., and Kenneth, W. B. 1994. Trace Elements in the Oceans. Trace Elements in Natural Waters. CRC Press, 247-80.

[26] Bruland, K. W., and Lohan, M. C. 2003. "Controls of Trace Metals in Seawater." Treatise on Geochemistry 6: 23-47.

[27] Dunning, A., and Major, C. W. 1974. "The Effect in Cold Sea Water of Oil Fractions uzpon the Blue Mussel Mytilus edulis." Aquatic Science Fisheries 5: 214-21.

[28] Lucas, A., and Roux, S. 1975. "Toxicity of Several Crude Oils in Relation to Muscel Larvae." Aquatic Science Fisheries 5: 223-5.

[29] Mazmanidi, N. D., Kovaleka, G. I., Kotov, A. M., Bazhashvili, T. R., Diasamadizi, N. M., and Zambakhidzi, N. P. 1976. "On the Effect of Petroleum Products on the Black Sea Hydrobiology." Marine Pollution Bulltein 6: 201-8.

[30] ASTM D859-05 Standard Test Method for Silica in Water.

[31] EN 1189:1996 Determination of phosphorus.

[32] SM4500-NO3-E.Cadmium Reduction Method. 